\title{
Música nas disciplinas de Didática de um Curso de Magistério em nível médio: aprendizagens colaborativas
}

Resumo: Este artigo tem como objetivo analisar a inserção da música nas disciplinas de Didática da Educação Infantil e Didática nas séries iniciais do Ensino Fundamental do Curso de Magistério em nível médio da Escola de Educação Básica de Araranguá-SC. O texto analisa documentos legais do governo federal e do estado de Santa Catarina sobre a legislação e normatização do curso de formação de professores em nível médio, além de autores que discutem a inserção da música nesta modalidade de ensino. A metodologia, de caráter qualitativo, incluiu observações de aulas das disciplinas de Didática do curso investigado e realização de entrevistas com a professora da disciplina e anotações no diário de campo. As análises apontam que a música está inserida nas disciplinas de Didática como facilitadora no processo de ensino aprendizagem das crianças, incluindo perspectivas cognitivas, recreativas, inclusivas, socializadoras ou musicais, por entenderem que a música é uma linguagem artística que faz parte do fazer docente com crianças pequenas. O estudo aponta que a música nas disciplinas de Didática do Curso de Magistério investigado contribui de muitas maneiras visando a aprendizagem de crianças, logo, seria relevante a inclusão de formação musical mais específica para as professoras deste curso. Tal formação poderia ampliar novas experiências musicais nas escolas, proporcionando mais conhecimentos e experiências sociais e artísticas.

Palavras-chave: Ensino de música. Curso de Magistério. Música na formação do professor.

\section{Introdução}

Este estudo é um recorte de uma pesquisa de doutorado que vem investigando sobre a educação integral e a música no Curso de Magistério, em nível médio, em uma escola estadual da cidade de Araranguá-SC. Este artigo tem como objetivo analisar a inserção da música nas disciplinas de Didática da Educação Infantil e Didática nas séries iniciais do Ensino Fundamental do Curso de Magistério em nível médio.

No currículo atual do Curso de Magistério do estado de Santa Catarina, a música está inserida nas disciplinas de Educação e Infância e Fundamentos Teórico-Metodológicos do Ensino de Artes. No entanto, outras disciplinas do curso podem usar a música com fins pedagógicos, sem necessariamente estar explícito nas ementas do curso o estudo da música. Nas disciplinas de Didática, objeto deste artigo, a música não consta nas ementas, mas está inserida

Conceição de Maria Cunha Universidade do Estado de Santa Catarina

ceicacunha@gmail.com Sérgio Luiz Ferreira de Figueiredo

Universidade do Estado de Santa Catarina

sergiofigueiredo.udesc@gmail.com 
nos conteúdos a serem estudados ao longo da formação de professores em nível médio.

Na ementa da disciplina Didática da Educação Infantil consta como conteúdo a ser estudado: "A educação infantil no Brasil: seu caráter específico de prática pedagógica concepções e finalidades. [...]. Organização do cotidiano na Educação Infantil: tempo, espaço, atividade". (SANTA CATARINA, 2010, p. 78, grifos nossos) A música não está explícita na ementa citada, mas permeia o campo das práticas pedagógicas na Educação Infantil. Nessa primeira etapa da Educação Básica, por exemplo, as atividades pedagógicas são arraigadas de música, sejam elas como atividades-fim ou momentos pedagógicos que envolvem a música como meio de aprendizagens às crianças pequenas.

As vivências musicais também estão implícitas na ementa da disciplina de Didática nas séries iniciais, quando o texto destaca as "[...] especificidades das ações pedagógicas para o ensino/ aprendizagem (Ed. Indígena, EJA, Quilombolas, Ed. do Campo. Atendimento Especial/Educação Especial)". (SANTA CATARINA, 2010, p. 78) O professor regente da disciplina tem autonomia em sala de aula para inserir práticas pedagógicas diversas visando o melhor desenvolvimento e aprendizado dos alunos, podendo a música está inserida nessas práticas.

A partir do exposto nas ementas apresentadas, alguns questionamentos nortearam a realização deste trabalho: 1) Como a música vem sendo abordada nas disciplinas de Didática do Curso de Magistério da Escola de Educação Básica de Araranguá? 2) Quais estratégias pedagógicas são utilizadas pela professora das disciplinas de Didática para inserir práticas musicais na Educação Infantil e séries iniciais do Ensino Fundamental? Quais os objetivos da música nas atividades didáticas propostas?

O texto está fundamentado na legislação brasileira que regulamenta o Curso de Magistério e seus desdobramentos na estrutura curricular, observando a inserção da música no currículo do curso e em pesquisas sobre o ensino da música neste curso de formação de professores. Metodologicamente, foram realizadas observações de aula em um Curso de Magistério, anotações no caderno de campo e entrevistas com a professora das disciplinas de Didática para as séries iniciais e Didática para a Educação Infantil. 


\section{A música nos currículos do curso de formação de professores em nível médio: uma breve apresentação}

A música foi uma disciplina obrigatória no currículo do antigo Curso Normal, denominado na atualidade no estado de Santa Catarina como Curso de Magistério. O Curso Normal formava professores para lecionarem nos jardins de infância e nas escolas de primeiras letras, correspondendo hoje a Educação Infantil e séries iniciais do Ensino Fundamental.

De acordo com documentos oficiais do governo brasileiro, no Período Imperial, o Decreto n ${ }^{\circ}$ 8.025, de 16 de março de 1881, regulamentou a Escola Normal para o município da Corte. O Art. $1^{\circ}$ do referido documento estabelece que "a Escola Normal tem por fim preparar professores primarios do $1^{\circ}$ e do $2^{\circ}$ gráo: o ensino nella distribuido será gratuito, destinado a ambos os sexos, e comprehenderá dous cursos - o de sciencias e lettras, e o de artes". (BRASIL, 1881) O Curso de Artes, contemplava as seguintes disciplinas no currículo obrigatório: "Calligraphia e desenho linear; Musica vocal; Gymnastica e Trabalhos de agulha (para as alumnas)". ${ }^{1}$ (BRASIL, 1881)

No final do Período Imperial, a reforma educacional proposta pelo governo, por meio do Decreto n 7.247 de 19 de abril de 1879, estruturou o currículo do Curso Normal, inspirado no modelo pedagógico da primeira Escola Normal no Brasil, fundada na cidade de Niterói, no ano de 1835. (KULESCA, 1998) Naquele contexto, a música fazia parte do currículo do Curso Normal como disciplina obrigatória, intitulada Música Vocal. No ano de 1888, um novo decreto foi criado regulamentando a Escola Normal estabelecendo melhores condições físicas para a formação de professores em nível médio, com salas para desenhos, biblioteca, ginásio, laboratório de física, sala para trabalhos manuais e criação de escolas de aplicação, abrangendo o jardim de infância e escola de primeiras letras. Nesse novo decreto, a música continuava no currículo do curso intitulada Música Vocal. (BRASIL, 1988)

Com a Proclamação da República, em 1889, novas mudanças foram efetivadas no Curso Normal. O Decreto $n^{\circ} 27$ de 12 de março de 1890 reformou o modelo pedagógico e administrativo do Curso Normal, sem excluir da grade curricular a música como disciplina obrigatória na formação de professores em nível médio, sendo, então, denominada Música, solfejo e canto coral. (SÃO PAULO, 1890) 
De acordo com Cordova (2016), no estado de Santa Catarina, a primeira Escola Normal pública foi instituída por meio do Decreto $n^{\circ} 155$, de 10 de junho de 1892, sendo denominada Escola Normal Catharinense. No currículo do curso constava a disciplina Música e Canto. Essa denominação permaneceu até ocorrer uma nova mudança educacional no estado de Santa Catarina, no ano de 1911. O estado reorganizou a proposta curricular do Curso Normal incluindo disciplinas que estavam mais próximas de uma formação não tradicionalista, inspirada na reforma curricular educacional do estado de São Paulo com um currículo "baseado em disciplinas de caráter instrutivo, educativo e pedagógico".Após a reorganização da proposta curricular, a disciplina de música foi denominada "Música (abundância de cantos)". (CORDOVA, 2016, p. 273) O canto no Curso Normal ganhou resistência com a aprovação da Decreto-Lei $n^{\circ} 4.993$, de 26 de novembro de 1942, que instituiu o Conservatório Nacional de Canto Orfeônico. O artigo $2^{\circ}$ da lei, estabelecia que uma das competências do Conservatório Nacional de Canto Orfeônico seria "a) formar candidatos ao magistério do canto orfeônico nos estabelecimentos de ensino primário e de grau secundário".(BRASIL, 1946) Nesse contexto, os músicos que realizavam o curso do Conservatório Nacional de Canto Orfeônico, obtinham a habilitação necessária para lecionarem em toda a Educação Básica, inclusive no Cursos Normal em todo o Brasil. (LEMOS JÚNIOR, 2011) A pesquisa de Jardim (2009, p. 21) destaca que o canto orfeônico tinha como objetivos "[...] promover a disciplina, o civismo, o sentido coletivo, despertar os sentimentos patrióticos por conter as características e os elementos formadores da identidade e da construção de uma cultura nacional". Essas especificidades do canto orfeônico foram amplamente defendidas nos cursos de formação de professores, porém, já havia demandas por novas abordagens pedagógicas e atividades musicais mais direcionadas ao fazer na sala de aula.

O revés do ensino obrigatório de música no Curso Normal aconteceu após a aprovação da Lei de Diretrizes e Bases (LDB) $n^{0}$ 5.692, de 11 de agosto de 1971. No Capítulo I, que tratava do Ensino de $1^{\circ}$ e $2^{\circ}$ graus, no artigo $7^{\circ}$, foi estabelecido: "Será obrigatória a inclusão de Educação Moral e Cívica, Educação Física, Educação Artística e Programas de Saúde nos currículos plenos dos estabelecimentos de $1^{\circ}$ e $2^{\circ}$ graus" (BRASIL, 1971), correspondendo, na atualidade, o ensino fundamental e ensino médio, respectivamente. No ano de 1973 o Conselho Federal de Educação (CFE), hoje 
denominado Conselho Nacional de Educação (CNE), normatizou a criação dos cursos superiores de Educação Artística, regulamentados pela Resolução n ${ }^{\circ}$ 23, de 23 de outubro de 1973, e pelo Parecer $n^{0}$ 1.284, de 9 de agosto de 1973. O curso de Educação Artística passou a ser oferecido como licenciatura curta inicialmente, sendo oferecido posteriormente a formação na licenciatura plena. Essas licenciaturas em Educação Artística incluíam as Artes Cênicas, as Artes Visuais, o Desenho Geométrico e a Música, considerando que o professor deveria atuar numa perspectiva polivalente, ou seja, ensinar as quatro áreas artísticas nas escolas.

[...] tal formação era realizada inicialmente em curso de licenciatura curta, com duração de dois anos, que oferecia uma habilitação geral em Educação Artística, preparando o professor para atuação com as quatro áreas no ensino de $1^{\circ}$ grau (equivalente ao ensino fundamental hoje). Posteriormente, a licenciatura plena, com 4 anos de duração, incluía nos dois últimos anos uma habilitação específica das artes e autorizava o professor a lecionar também no segundo grau (equivalente ao ensino médio hoje). (FIGUEIDEDO, 2017, p. 82)

A música deixou de ser uma disciplina obrigatória oferecida em toda a educação básica, consequentemente, nos cursos de formação de professores em nível médio. Com a aprovação da atual LBD n ${ }^{\circ}$ 9.394, de 20 de dezembro de 1996, o ensino de Arte passou a ser referenciado na lei. No Capítulo II que trata da educação básica, o § $2^{\circ}$ estabeleceu que "o ensino da arte constituirá componente curricular obrigatório, nos diversos níveis da educação básica, de forma a promover o desenvolvimento cultural dos alunos". (BRASIL, 1996) No ano de 2008 foi aprovada a Lei no 11.769 que tornou obrigatório o ensino de música na educação básica. A lei determinava que "A música deverá ser conteúdo obrigatório, mas não exclusivo, do componente curricular de que trata o § 2 deste artigo" (BRASIL, 2008), evidenciando, consequentemente, que a música deveria ser ensinada nos cursos de formação de professores, por este fazer parte do ensino médio. A LDB nº 9.394/96 vem passando por constantes mudanças visando atender às demandas educacionais que permeiam a educação básica. Com este propósito, novas redações alteraram o parágrafo referente ao ensino de artes. A Lei $n^{0} 13.278$, de 2 de maio de 2016, alterou o texto da LDB referente ao ensino da arte na educação básica: "As artes visuais, 
a dança, a música e o teatro são as linguagens que constituirão o componente curricular de que trata o $\S 2$ deste artigo" (BRASIL, 2016a), substituindo o texto da Lei $n^{0}$ 11.769/08 que indicava o ensino de música obrigatório. Ainda em 2016 foi homologada a Resolução $n^{\circ}$ 2, do Conselho Nacional de Educação referente às Diretrizes Nacionais para a operacionalização do ensino de Música na Educação Básica. (BRASIL, 2016b) Tal resolução "tem por finalidade orientar as escolas, as Secretarias de Educação, as instituições formadoras de profissionais e docentes de Música, o Ministério da Educação e os Conselhos de Educação para a operacionalização do ensino de Música na Educação Básica". (BRASIL, 2016b, art. 1) A referida resolução pautou-se nas demandas da Lei no 11.769/08, que foi substituída pela Lei $n^{\circ} 13.278 / 16$, mas continua válida, orientando diversos aspectos referentes ao ensino de música na escola brasileira.

Cabe destacar que tais diretrizes incluem, também, a necessidade de contratações de profissionais licenciados em música, por parte das Secretarias de Educação: "realizar concursos específicos para a contratação de licenciados em Música". (BRASIL, 2016b, art. 1, par. 2, item VII) Além disso, a formação continuada em música é também destacada na resolução, com o propósito de qualificar os profissionais que atuam na educação básica.

A última alteração na LDB referente ao ensino de arte na educação básica foi em 2017, sendo que o parágrafo 2 passou a ser assim especificado: "o ensino da arte, especialmente em suas expressões regionais, constituirá componente curricular obrigatório da educação básica". (BRASIL, 2017)

As alterações da LDB vigente sobre o ensino de arte contemplam toda a educação básica. O curso de formação de professores em nível médio, neste artigo identificado como Curso de Magistério, faz parte da educação básica, podendo ser um curso oferecido de forma concomitante ou subsequente ao ensino médio. O curso está amparado pela atual LDB e habilita professores, em nível médio, para lecionarem na Educação Infantil e nas séries iniciais do ensino fundamental. No artigo 62 da lei estabelece que:

A formação de docentes para atuar na educação básica far-se-á em nível superior, em curso de licenciatura plena, admitida, como formação mínima para o exercício do magistério na educação infantil e nos cinco primeiros anos do ensino 
fundamental, a oferecida em nível médio, na modalidade normal. (BRASIL, 2017)

Com suas especificidades, o curso é regulamentado pelas Diretrizes Curriculares Nacionais para a formação de professores na Modalidade Normal em nível médio. (BRASIL, 1999) As secretarias de educação dos estados são responsáveis por organizar os currículos do curso, oferecendo gratuitamente na rede pública a formação de professores em nível médio.

\section{A música na formação do professor em nível médio}

A música na formação do professor formado em nível médio é um habitus construído ao logo do processo do Curso Normal, neste contexto específico, denominado Curso de Magistério. De acordo com Bourdieu (1983, p. 104, grifos do autor), "o habitus, como diz a palavra, é aquilo que se adquiriu, mas que se encarnou no corpo de forma durável sob a forma de disposições permanentes". Para Bourdieu, o habitus está relacionado com a formação de um campo, o locus, cujos atores sociais são conduzidos a desenvolver questões práticas, de forma durável. "A prática, conjunção do habitus e da situação, ocorre desta forma no seio de um campo que transcende as relações entre os atores". (BOURDIEU, 1994, p. 19) Segundo o autor, as relações cotidianas dos atores sociais com questões práticas contribuem para a formação de um campo, buscando resolver problemas objetivados na prática, fixando-os como um habitus.

Esta síntese do amplo debate de Bourdieu sobre a formação de um campo e o habitus contribui para que possa ser compreendido como a música foi implantada no curso de formação de professores em nível médio e como ela ainda permanece no Curso de Magistério investigado. Os estudos apresentados corroboram para a formação desse habitus na formação do professor em nível médio.

Oliveira (2004) investigou o canto coletivo na disciplina de música nas primeiras décadas do século XX na formação de professores no Curso Normal de Belo Horizonte (MG), analisando um repertório de canções escolares relacionadas com o pensamento educacional no início do século passado, destacando a música na educação de crianças e no Curso Normal. A pesquisadora destacou que na formação musical no curso investigado predominou o canto, contribuindo "[...] para valorizar a formação de um pensamento e 
de uma prática docentes relativos ao canto como uma disciplina escolar, durante o período estudado". (OLIVEIRA, 2004, p. 97) O canto, trabalhado coletivamente, foi uma das atividades musicais utilizadas pelos professores de música como estratégia para ensinar canções escolares e cívicas.

Jardim (2004), ao estudar a legislação educacional na Primeira República, destacou que os legisladores da época tinham um entendimento de que os ensinamentos musicais repassados aos professores seriam também aplicados às crianças pequenas, já que os estudantes do Curso Normal estariam, em breve, nas salas de aula. Os professores que lecionavam as disciplinas de música no Curso Normal primavam pela atividade do canto coral, por possibilitar a prática em conjunto. O repertório era formado, na maioria, por músicas europeias, tendo também "os cânticos escolares e cívicos". (JARDIM, 2004, p. 5) A autora destaca que, mesmo sem uma formação pedagógica musical específica dos professores que lecionavam a disciplina de música no antigo Curso Normal, a disciplina sempre esteve presente no currículo do curso, por compreenderem que a música contribuiria para o desenvolvimento da sensibilidade do educando.

O ensino da música, objetivando um repertório que atendesse às necessidades pedagógicas e atividades cotidianas da escola, foi observado na pesquisa de Fuks (1991). Investigando a formação de professores em uma Escola Normal, a pesquisadora discutiu o ensino da música na formação de professores nos anos de 1980. Com as análises da pesquisa de campo, a autora destacou que na Escola Normal investigada, o ensino da música apresentava diferentes metodologias, imbricadas às mudanças políticas, concepções de ensino e história da educação musical, prevalecendo heranças do canto orfeônico, repertório de hinos cívico-escolares e cânticos enfatizando os trabalhos do dia a dia na escola. Em outro estudo, Fuks (1992) enfatizou que a música estava direcionada para atividades pertinentes à rotina escolar de crianças pequenas, denominando-a de "música de comando", ou seja, música para o horário do lanche, dormir, fazer fila, realizar tarefas, mas sem discussões relacionadas ao ensino da música na formação da criança.

Após a aprovação da LDB n 9.394/96, Fuks realizou novas pesquisas em três escolas que ofereciam o Curso de Magistério, antigo Curso Normal, visando conhecer as novas abordagens de ensino de música no curso de formação de professores em nível 
médio, a partir da nova LDB. A autora relatou que, mesmo após a aprovação da nova LDB e seus desdobramentos, os alunos dos Cursos de Magistério investigados continuam solicitando aos professores "músicas introdutórias para as diversas atividades diárias". (FUKS, 2005, p. 104) Os alunos acreditam ser necessário, na formação docente, conhecer um repertório de músicas pedagógicas que auxiliem nas atividades em sala de aula.

No ano de 2005, Fuks fez novas observações quanto ao ensino da música na antiga Escola Normal do Rio de Janeiro. Com as mudanças na LDB nº 9.394/96, a pesquisadora objetivou conhecer os impactos dessa lei na escola que investigou no anos de 1980 e constatou que a disciplina de música ainda fazia parte da grade curricular do curso de formação de professores em nível médio. Mas, de acordo com ela, os alunos atuais ainda pediam aos professores um repertório que incluísse "musiquinhas de comando". A autora reforçou que a herança dessas práticas musicais ainda persiste nas escolas de formação para o Magistério.

\section{A música nas disciplinas de Didática do Curso de Magistério: cantar, brincar e aprender}

O Curso de Magistério investigado existe há mais de 50 anos na cidade de Araranguá-SC. A Escola de Educação Básica de Araranguá hoje é uma escola de Ensino Médio, mas já foi denominada Escola Normal de Araranguá, pioneira no extremo sul catarinense na formação de professores em nível médio. Atualmente a escola oferece o curso subsequente ao ensino médio, com duas turmas, sendo uma de $3^{\circ}$ e outra de $4^{\circ}$ Magistério no período noturno. De acordo com informações obtidas no campo da pesquisa, muitos alunos que realizaram o curso já possuíam formação superior e, na atualidade, existem alunas com formação superior e graduandas em Pedagogia que buscam este Curso de Magistério em nível médio para adquirirem mais conhecimentos didáticos e pedagógicos que possam ampliar suas formações para a docência.

Na configuração atual, o Curso de Magistério não oferece uma disciplina específica de música. De acordo com as ementas do curso, a música está oficialmente presente nas disciplinas de Fundamentos Teórico-Metodológicos do Ensino de Artes e Educação e Infância. 
Educação e Infância - Criança e Infância: conceituação. Construção social da infância e determinações sócio-históricas. Educação, infância e sociedade. Bases conceituais: jogos, brinquedo e brincadeira; pensamento e linguagem; interações sociais. Processos de formação do pensamento: conceitos espontâneos e científicos. Contribuição da brincadeira, das interações e das linguagens (não-verbal, verbal, gestual, corporal, plástica, pictórica e musical) no processo de aprendizagem e desenvolvimento da criança. A produção cultural das e para as crianças.

\section{Fundamentos Teórico-metodológicos do Ensino de Artes}

- Estudo das questões filosóficas que norteiam o ensino das artes. A evolução gráfica e estética e consequente abordagem de artes levando em conta a realidade, a escola e a comunidade da criança. O imaginário como fonte de conhecimento e estrutura artística na criança. Arte-Educação. Estudo das artes visuais, da música, da dança e do teatro com orientações didáticas e metodológicas para a educação infantil e séries iniciais do ensino fundamental. O imaginário como fonte de conhecimento e estrutura artística na criança. Diversidade cultural, artes visuais, música, dança, teatro e escola. (SANTA CATARINA, 2010, p. 80-81)

Nas ementas citadas, a música deve ser trabalhada durante os processos lúdicos na Educação Infantil e séries iniciais do Ensino Fundamental, contribuindo no processo de desenvolvimento integral da criança. Os conteúdos musicais devem ser ponderados nas brincadeiras, nas interações sociais em sala de aula, no desenvolvimento das linguagens artísticas, corporal, linguística, estimulando o imaginário da criança.

No Curso de Magistério investigado, além das duas disciplinas citadas que incluem a música nas suas ementas, outras disciplinas do curso também usam a música como um recurso pedagógico no decorrer do ano letivo. No entanto, para este trabalho, a música será analisada e discutida nas disciplinas de Didática do Curso de Magistério. Nas ementas das disciplinas de Didática não constam a música como um conteúdo obrigatório a ser estudado durante o curso, no entanto, as disciplinas de Didática para Educação Infantil e Didática para as séries iniciais do ensino fundamental chamaram atenção pelo teor pedagógico e musical observados durante as aulas daquelas disciplinas. 
Salienta-se que a professora investigada é pedagoga, bem como, leciona na rede pública do município de Turvo-SC, em turmas de alfabetização. No seu processo formativo, nunca participou de curso de música na Educação Básica. Na escola que leciona as disciplinas de Didática para Educação Infantil e Didática para as séries iniciais do Ensino Fundamental, a professora não dispõe de um espaço físico mais apropriado para as atividades musicais. A sua experiência prática de música fora da escola é com o coral da igreja que participa. No entanto, como professora alfabetizadora, compreende e sente falta de formação musical para melhorar também os seus fazeres musicais com as crianças que leciona, mas enfatiza a relevância de trabalhar com a música nas disciplinas que ministra no Curso de Magistério, haja vista a demanda pedagógica de se trabalhar com a música com crianças pequenas.

Durante as observações de aulas a professora das disciplinas solicitou às alunas do $3^{\circ}$ Magistério que organizassem um caderno com diversas músicas infantis, apontando sempre os objetivos a serem trabalhados em sala de aula para cada música. Na turma do $4^{\circ}$ Magistério, ela solicitou às alunas que apresentassem, no início de cada aula, uma atividade incluindo uma música já escrita no caderno produzido no ano anterior. O caderno de cada aluna continha as letras das músicas.

A experiência de construir um caderno com músicas no Curso de Magistério, de acordo com o relato da professora das disciplinas, é uma herança de professores do curso que frequentou em período anterior. Durante as entrevistas, a professora informou que é ex-aluna do Curso de Magistério, realizado em uma escola estadual da cidade de Turvo-SC, nos anos de 1990, e que também participou da experiência de organizar um caderno com músicas infantis durante aquele curso.

Quando eu fiz o Magistério, também elaborei um caderno musical e isso me ajudou muito nas atividades com as crianças. A professora, na época, cobrava a cada aula uma música e os alunos deveriam copiar uma nova música no quadro. Muitas vezes, eu nem conhecia a música, mas copiava. Eram muitas músicas infantis, mas nem sempre eu sabia cantar aquelas músicas.(Entrevista com a Professora de Didática, 2019)

As músicas infantis que a professora conhecia, ajudam ainda hoje nas suas atividades pedagógicas com alunos das séries iniciais, 
fortalecendo a ideia de que a música pode contribuir nas aprendizagens das crianças.

\begin{abstract}
Nas minhas atividades na escola, como sou professora alfabetizadora, costumo usar músicas quando estamos trabalhando algumas letras, sílabas. [...]. Eu costumo usar muito a música, até porque ajuda as crianças na memorização, elas gostam e aprendem mais rápido, porque aprendem a cantar rápido e não esquecem as músicas. (Entrevista com a Professora de Didática, 2019)
\end{abstract}

Essa herança do canto na escola pode ser um dos reflexos da constante presença do cantar na formação de professores no antigo currículo do Curso Normal. Cordova (2016), quando analisou a antiga Escola Normal na cidade de Lajes-SC, citou que o currículo do Curso Normal do estado de Santa Catarina, no ano de 1911, deixou evidente que a disciplina de música deveria ter muita música cantada, oferecendo uma "abundância de cantos". (CORDOVA, 2016, p. 273) A organização de um caderno com música infantis, confirma, de certa forma, essa "abundância" de cantos na formação dos professores em nível médio.

A partir da experiência com um caderno musical na formação em nível médio da professora investigada, assim como a prática docente como professora alfabetizadora que utiliza a música em várias atividades pedagógicas, a professora entrevistada considera importante repassar para as alunas do Curso de Magistério os benefícios que tais experiências musicais podem promover. A organização do caderno com músicas infantis é uma estratégia pedagógica que pode auxiliar as alunas em atividades na sala de aula, podendo contribuir no processo de aprendizagem das crianças na alfabetização, memorização, socialização, inclusão, desenvolvimento motor e entretenimento. Como exemplo, a professora citou atividades para o desenvolvimento social da criança:

Fizemos outras atividades, dinâmicas em sala para trabalhar a socialização das crianças. E elas usaram muitas musiquinhas infantis nas atividades de socialização: cantigas de roda, músicas infantis, atividades que as crianças gostam e ajudam na socialização. (Entrevista com a Professora de Didática, 2019)

Nas aulas observadas da disciplina de Didática para os anos iniciais, uma aluna do curso propôs uma atividade musical com o objetivo de trabalhar a coordenação motora das crianças. Em cír- 
culo, todas as alunas sentaram no chão da sala de aula e cantaram a música "Escravos de Jó". Cada aluna portava um tubo de papel e deveria cantar a música repassando o tubo para a colega da esquerda, fazendo com que todos os tubos circulassem em sentido horário. As alunas cantaram, mas os tubos, em nenhuma tentativa, circularam simultaneamente no sentido horário, pois não foi realizado nenhum trabalho com as alunas sobre o tempo da música, a pulsação, o ritmo. Este trabalho mais especificamente musical seria fundamental para a realização satisfatória da atividade. A aluna que coordenou a atividade em nenhum momento comentou essa necessidade de lidar adequadamente com a pulsação ou com o tempo da música, salientando apenas que as colegas da turma estavam desatentas e que não sabiam realizar essa brincadeira.

Outra música apresentada por uma aluna foi "O sapo não lava o pé". A aluna cantou a música com as colegas e depois cantou a mesma música em Libras. O objetivo era ensinar para as crianças alguns sinais em Libras das palavras: sapo, pé, lagoa, lavar, morar, usando a música como recurso pedagógico. As alunas observavam o sinal da palavra e repetiam. Posteriormente, todas cantaram a música "O sapo não lava o pé" realizando os sinais em Libras.

Na aula da disciplina de Didática para Educação Infantil, uma das alunas apresentou a música "Ciranda dos bichos", do grupo musical Palavra Cantada. Primeiramente ela apresentou a música para a turma por meio de um aparelho de som. Depois ela entregou para cada colega da sala a figura de um animal citado na música. As alunas ficaram em círculo cantando a música e segurando a figura de um animal. Quando a música citava o nome do animal, a aluna que estava segurando a figura daquele animal ia para o centro do círculo e dançava fazendo imitações do referido animal. E assim foi sendo repetido até que todas as alunas do curso imitassem os animais citados na música. Os objetivos da atividade, de acordo com a aluna que propôs a atividade, foram estimular a coordenação motora, conhecer os bichos citados na música e trabalhar a socialização.

As músicas copiadas nos cadernos por cada aluna não passaram por nenhuma interferência da professora. Em nenhum momento ela solicitou que as alunas copiassem músicas no quadro, por já ter refletido no seu processo de aprendizagem, quando realizou o Curso de Magistério, que as músicas só fariam sentido se as alunas conhecessem o repertório e soubessem se apropriar das letras para 
fins pedagógicos a serem trabalhadas com as crianças. As músicas apresentadas faziam parte do cancioneiro popular infantil e outras da mídia.

\section{Considerações finais}

A música, no Curso de Magistério investigado, está presente não só nas disciplinas cujas ementas citam a música no processo formativo dos estudantes do curso. As disciplinas de Didática chamaram a atenção por oferecerem às alunas do curso várias possibilidades de inserirem a música como um recurso pedagógico em prol de aprendizagens para as crianças.

O fato do curso não oferecer uma disciplina específica de música no currículo não inviabiliza a presença de atividades musicais diversas no desenvolvimento prático das disciplinas. No entanto, foi observada a necessidade de se trabalhar elementos musicais específicos para o desenvolvimento satisfatório de alguns tipos de atividade. Ou seja, elementos rítmicos, melódicos, fraseológicos, formais, poderiam compor parte do processo formativo musical das professoras no Curso de Magistério em nível médio.

Constatou-se que o habitus construído ao longo das vivências musicais ao longo da história do curso de formação de professores em nível médio ainda se reflete no Curso de Magistério investigado. As disciplinas de Didática para a Educação Infantil e Didática para as séries iniciais do Ensino Fundamental corroboram para que a música esteja presente nas atividades pedagógicas em sala de aula, promovendo aprendizagens diversas que integram a formação do professor e, consequentemente, da criança.

Atividades musicais como facilitadoras de processos de aprendizagem também puderam ser observadas, reiterando sua relevância e sua função auxiliar para a música na escola. A música pode favorecer a aprendizagem diversas na escola, pode auxiliar na memorização de conteúdos, nos processos de socialização, dentre outras funções. Considerando essa possibilidade da música contribuir de muitas maneiras para a aprendizagem das crianças, seria relevante a inclusão de formação musical específica para estas professoras do Curso de Magistério. A formação específica poderia ampliar o alcance das experiências musicais na escola, apresentando e utilizando a música não apenas como acessório para a aprendizagem de algo, mas como forma de conhecimento 
e de experiência social e artística. Destaca-se que a escola investigada e a Secretaria de Educação do estado de Santa Catarina não oferecem formação continuada em música, sendo que o trabalho musical na formação das professoras em nível médio vem dependendo de iniciativas pessoais da professora. A música está presente nas ementas de algumas disciplinas, tornando um conteúdo obrigatório a ser trabalhada durante o $3^{\circ}$ Magistério e o $4^{\circ}$ Magistério, no entanto, faltam professores com mais formação na área para ampliar os conhecimentos musicais pertinentes à educação básica, como uma atividade-fim que proporcionará mais aprendizagens artísticas aos discentes.

Experiências musicais podem contribuir de várias maneiras no processo formativo nos diversos níveis da Educação Básica, muitas vezes ocupando papel coadjuvante para aprendizagens diversas, ou seja, a música é muitas vezes utilizada como meio para se desenvolver diferentes aspectos de outras disciplinas. No entanto, é importante considerar a formação musical de maneira autônoma, como área de conhecimento que possui conteúdos e metodologias próprias, valorizando e oferecendo experiências significativas para os estudantes de todos os níveis escolares. Para que se alcance este propósito, é fundamental que se considere e se invista na formação adequada de profissionais da educação que atuam em tais níveis escolares, sejam eles professores generalistas ou professores especialistas licenciados em música.

Finalizando este trabalho, cabe destacar que a presença da música na formação das professoras em nível médio é aspecto positivo, considerando a organização curricular. No entanto, o aprofundamento da experiência e da formação musical na trajetória formativa das professoras poderia contribuir para a inserção de uma educação musical significativa e com qualidade nas séries iniciais da escola, seja na Educação Infantil, seja nas séries iniciais do Ensino Fundamental. Experiências diversas nesse sentido têm sido discutidas na literatura com relação ao ensino de música na formação e na atuação de professores da Educação Infantil e dos anos iniciais do Ensino Fundamental (BELLOCHIO, 2017; FIGUEIREDO, 2017; FURQUIM; BELLOCHIO, 2010) e tais discussões poderiam ser incorporadas no universo dos Cursos de Magistério, contribuindo ainda mais para o desenvolvimento musical de profissionais da educação. 


\title{
Music in the Didactics disciplines of a Teaching Course at medium level: collaborative learning
}

\begin{abstract}
This article aims to analyze the insertion of music in the didactic of children's education and didactic in the elementary school's early grades of the Magisterium Course at the middle level of the Basic Education School of Araranguá-SC. The text analyzes legal documents from the federal government and the state of Santa Catarina on the legislation and of the standardization of teacher's training course at medium level, in addition to authors discussing the insertion of music in this mode of teaching. The methodology, of qualitative character, included classes observations of didactic lessons, regarding the investigated course and conduct of interviews with the teacher and notes in the field diary. The analyzes indicates that music is inserted in the didactic disciplines as a facilitator in the children's learning process, including cognitive, recreational, inclusive, socializing or musical perspectives, as they understand that music is an artistic language that is part of teaching with small children. The study points out that music in the didactic classes of the investigated course contributes in many ways aiming at children's learning, therefore, it would be relevant to include more specific musical training for this course teachers. Such training could expand new musical experiences in schools, providing more knowledge, social and artistic experiences.
\end{abstract}

Keywords: Music teaching. Teaching Course. Music in teacher education.

\section{La música en las disciplinas didácticas de um curso de enseñanza a nível secundaria: aprendizaje colaborativo}

Resumen: Este artículo tiene como objetivo analizar la inserción de la música en la Didáctica de la Educación Infantil y la Didáctica en los primeiros grados de la escuela primaria del Curso de Enseñanza en el nivel secundario de la Escuela de Educación Básica de Ararangá-SC. El texto analiza documentos legales del gobierno federal y del estado de Santa Catarina sobre la legislación y la regulacion del curso de formación de docentes de secundaria, además de autores que discuten la inserción de la música en esta modalidad de enseñanza. La metodología, de caráter cualitativo, incluyó observaciones de clases de disciplinas didácticas del curso investigado y realización de entrevistas con la profesora de la disciplina y notas en el diario de campo. Los análisis muestran que la música se inserta en las disciplinas didácticas como un facilitador en el proceso de enseñanza del aprendizaje de los niños, incluídas las perspectivas cognitiva, recreativa, inclusiva, socializadora o musical, ya que entienden que la música es um lenguaje artístico que forma parte de la enseñanza con niños pequeños. El estudio señala que la música en las disciplinas didácticas de curso de enseñanza investigado contribuye de muchas maneras al aprendizaje de los niños, por lo tanto, seria relevante incluir una formación musical más específica para las profesoras de este curso. Dicha capacitación podria expandir nuevas experiencias musicales en las escuelas, proporcionando más conocimeieto y experiencias sociales y artísticas.

Palabras clave: enseñanza de la música. Curso de enseñanza. La música en la formación del professorado. 


\section{Referências}

BELLOCHIO, Cláudia Ribeiro (org.). Educação musical e unidocência: pesquisas, narrativas e modos de ser do professor de referência. Porto Alegre: Sulina, 2017.

BOURDIEU, Pierre. Questões de sociologia. Rio de Janeiro: Marco Zero, 1983.

BOURDIEU, Pierre. Esboço de uma teoria da prática. In: ORTIZ, Renato (org.). Pierre Bourdieu. São Paulo: Ática, 1994. p. 46-81.

BRASIL. Decreto-Lei $n^{\circ} 4.993$, de 26 de novembro de 1942. Institui o Conservatório Nacional de Canto Orfeônico, e dá outras providências. Rio de Janeiro, 1942. Disponível em: https://www2.camara.leg.br/ legin/fed/declei/1940-1949/decreto-lei-4993-26-novembro-1942-415031publicacaooriginal-1-pe.html. Acesso em: 26 nov. 2019.

BRASIL. Lei, $n^{0}$ 5.692, de 11 de agosto de 1971. Fixa Diretrizes e Bases para o ensino de $1^{\circ}$ e $2^{\circ}$ graus, e dá outras providências. Brasília, 1971. Disponível em: https://www2.camara.leg.br/legin/fed/lei/1970-1979/ 1ei-5692-11-agosto-1971-357752-publicacaooriginal-1-pl.html. Acesso: 28 nov. 2019.

BRASIL. Decreto $n^{\circ}$ 8.025, de 16 de março de 1881. Manda executar o novo Regulamento para a Escola Normal do municipio da Côrte. Rio de Janeiro: Palácio do Rio de Janeiro, 1881. Disponível em: https://www2. camara.leg.br/legin/fed/decret/1824-1899/decreto-8025-16-marco-1881546192-publicacaooriginal-60106-pe.html. Acesso em: 26 nov. 2019.

BRASIL. Decreto $n^{0} 10.060$, de 13 de outubro de 1888. Dá novo Regulamento à Escola Normal. Rio de Janeiro: Palácio do Rio de Janeiro, 1888. Disponível em: https://www2.camara.leg.br/legin/ fed/decret/1824-1899/decreto-10060-13-outubro-1888-542876publicacaooriginal-52485-pe.html. Acesso em: 16nov.2019.

BRASIL. Lei $n^{\circ}$ 9.394, de 20 de dezembro de 1996. Estabelece as diretrizes e bases da educação nacional. Brasília, DF: Casa Civil, 1996. Disponível em: http://www.planalto.gov.br/ccivil_03/Leis/L9394.htm. Acesso em: 7nov. 2019.

BRASIL. Lei $n^{\circ}$ 11.769, de 18 de agosto de 2008. Altera a Lei n 9.394, de 20 de dezembro de 1996, Lei de Diretrizes e Bases da Educação, para dispor sobre a obrigatoriedade do ensino da música na educação básica. Brasília, DF: Casa Civil, 2008. Disponível em: http://www.planalto.gov. br/ccivil_03/_Ato2007-2010/2008/Lei/L11769.htm\#art1. Acesso em: 13 nov. 2019.

BRASIL. Lei $n^{\circ} 13.278$, de 2 de maio de 2016. Altera o $\S 6^{\circ}$ do art. 26 da Lei $n^{\circ}$ 9.394, de 20 de dezembro de 1996, que fixa as diretrizes e bases da educação nacional, referente ao ensino da arte. Brasília, DF: Secretaria-Geral, 2016a. Disponível em: http://www.planalto.gov.br/ ccivil_03/_Ato2015-2018/2016/Lei/L13278.htm\#ART1. Acesso em: 13 nov. 2019. 
BRASIL. Lei $n^{\circ}$ 13.415, de 16 de fevereiro de 2017. Altera as Leis n ${ }^{\circ}$ 9.394, de 20 de dezembro de 1996, que estabelece as diretrizes e bases da educação nacional, e 11.494, de 20 de junho 2007, que regulamenta o Fundo de Manutenção e Desenvolvimento da Educação Básica e de Valorização dos Profissionais da Educação, a Consolidação das Leis do Trabalho - CLT, aprovada pelo Decreto-Lei $n^{\circ} 5.452$, de $1^{\circ}$ de maio de 1943, e o Decreto-Lei $n^{\circ}$ 236, de 28 de fevereiro de 1967; revoga a Lei $n^{\circ}$ 11.161, de 5 de agosto de 2005; e institui a Política de Fomento à Implementação de Escolas de Ensino Médio em Tempo Integral. Brasília, DF: Secretaria-Geral, 2017. Disponível em: http://www. planalto.gov.br/ccivil_03/_Ato2015-2018/2017/Lei/L13415.htm\#art7. Acesso em: 13 nov. 2019.

BRASIL. Ministério da Educação. Conselho Nacional de Educação. Câmara de Educação Básica. Resolução nº 2, de 10 de maio de 2016. Define Diretrizes Nacionais para a operacionalização do ensino de Música na Educação Básica. Diário Oficial da União, Brasília, DF, $2016 b$. Disponível em http:// portal.mec.gov.br/index.php?option =com_ docman\&view = downloadEalias = 40721-rceb002-16-pdf\&́category_ slug $=$ maio-2016-pdfÉ Itemid =30192. Acesso em: 10 out. 2019.

BRASIL. Ministério da Educação. Conselho Nacional de Educação. Câmara de Educação Básica. Resolução CEB nº 2, de 19 de abril de 1999. Institui Diretrizes Curriculares Nacionais para a Formação de Docentes da Educação Infantil e dos anos iniciais do Ensino Fundamental, em nível médio, na modalidade Normal. Diário Oficial da União, Brasília, DF, 1999. Disponível em: http://portal.mec.gov.br/cne/arquivos/pdf/ rceb02_99.pdf. Acesso em: 13 nov. 2019.

FIGUEIREDO, Sergio Luiz Ferreira de. A música e as artes na formação do pedagogo: polivalência ou interdisciplinaridade? Revista da FAEEBA: educação e contemporaneidade, Salvador, v. 26, n. 48, abr. 2017. Disponível em: https://revistas.uneb.br/index.php/faeeba/article/ view/7567/4914. Acesso em: 27 nov. 2019.

FUKS, Rosa. Estará Morta a Escola Normal Pública? Revista da ABEM, Porto Alegre, ano 1, n. 1, p. 41-47, maio 1992. Disponível em: http:// abemeducacaomusical.com.br/revista_abem/ed1/revista1_artigo5.pdf. Acesso em: 2 dez. 2019.

FUKS, Rosa. Tradição/contradição na prática musical de uma escola formadora de professores. OPUS: revista da Associação Nacional de Pesquisa e Pós-Graduação em Música, ano 3, n. 3, p. 25-35, set. 1991. Disponível em: https://www.anppom.com.br/revista/index.php/opus/ article/view/26/128. Acesso em: 2 dez. 2019.

FUKS, Rosa. O novo sentido do silêncio na Escola Normal: considerações acerca da música da instituição em dois tempos (anos oitenta e noventa) In: CONGRESSOS DA ASSOCIAÇÃO NACIONAL DE PESQUISA E PÓS-GRADUAÇÃO EM MÚSICA - ANPPOM, 15., 2005, Rio de Janeiro. Anais [...]. Rio de Janeiro: ANPPOM, 2005. p. 100-108. Disponível em: https://antigo.anppom.com.br/anais/anaiscongresso_ anppom_2005/sessao2/rosa_fuks.pdf. Acesso em: 2 dez. 2019. 
FURQUIM, Alexandra Silva dos Santos; BELLOCHIO, Cláudia Ribeiro. A formação musical de professores unidocentes: um estudo em cursos de pedagogia do Rio Grande do Sul. Revista da ABEM, Porto Alegre, v. 24, p. 54-63, set. 2010.

JARDIM, Vera Lúcia Gomes. Os sons da república: o ensino da música nas escolas públicas de São Paulo na Primeira República 1889-1930. In: REUNIÃO ANUAL DA ANPED. Caxambu, 2004. Disponível em: http:// www.anped.org.br/sites/default/files/t0214.pdf. Acesso em: 3 abr. 2018.

JARDIM, Vera Lúcia Gomes. Institucionalização da profissão docente - o professor de música e a educação pública. Revista da Abem, nº 21, março de 2009. Disponível em: http://www.abemeducacaomusical.com.br/ revista_abem/ed21/revista21_artigo2.pdf. Acesso em: 04 nov. 2019.

KULESZA, Wojciech Andrzej. A institucionalização da Escola Normal no Brasil (1870-1910). Revista Brasileira de Estudos Pedagógicos, Brasília, DF, v. 79, n. 193, p. 63-71, set./dez. 1998. Disponível em: http://rbep. inep.gov.br/ojs3/index.php/rbep/article/view/1243. Acesso em: 28 nov. 2019.

LEMOS JÚNIOR, Wilson. O ensino do Canto Orfeônico na escola secundária brasileira (décadas de 1930 e 1940). Revista HISTEDBR, Campinas, n. 42, p. 279-295, jun. 2011. Disponível em: http://www. histedbr.fe.unicamp.br/revista/edicoes/42/art18_42.pdf. Acesso em: 25 nov. 2019.

OLIVEIRA, Flávio Couto e Silva de. O canto civilizador: música como disciplina escolar nos ensinos primário e normal de Minas Gerais, durante as primeiras décadas do século XX. 2004. Tese (Doutorado em Educação) - Faculdade de Educação, Universidade Federal de Minas Gerais, Belo Horizonte, 2004. Disponível em: http://www. bibliotecadigital.ufmg.br/dspace/bitstream/handle/1843/FAEC85NQDX/tese.pdf?sequence =1. Acesso em: 4 dez. 2019.

SANTA CATARINA. Orientações para organização e funcionamento das unidades escolares de educação básica e profissional da rede pública estadual - 2011. Florianópolis, SC: Secretaria de Educação Básica, 2010.

SÃO PAULO. Assembleia Legislativa. Decreto $n^{\circ}$ 27, de 12 de março de 1890. Reforma a Escola Normal e converte em Escolas Modelos as Escolas anexas. São Paulo: Secretaria Geral Parlamentar, 1890. Disponível em: https://www.al.sp.gov.br/repositorio/legislacao/ decreto/1890/decreto-27-12.03.1890.html. Acesso em: 28 nov. 2019.

SPANAVELLO, Caroline Silveira; BELLOCHIO, Cláudia Ribeiro. Educação musical nos anos iniciais do ensino fundamental: analisando as práticas educativas de professores unidocentes. Revista da ABEM, Porto Alegre, v. 12, 89-98, mar. 2005. Disponível em: http://www. abemeducacaomusical.com.br/revista_abem/ed12/revista12_artigo11. pdf. Acesso em: 5 dez. 2019. 
